\title{
Understanding Urban Teachers' Perceptions for Professional Development in Classroom Management
}

\author{
Sarup R. Mathur, Associate Professor (corresponding author) \\ Mary Lou Fulton Teachers College, Arizona State University, Tempe, AZ 85287-1811 \\ Tel: 480-965-6893 E-mail: sarup.mathur@asu.edu \\ Scott C. Marley, Associate Professor \\ Mary Lou Fulton Teachers College, Arizona State University, Tempe, AZ 85287-1811 \\ Tel: 480-727-7237 E-mail: Scott.Marley@asu.edu
}

Received: July 30, 2015 Accepted: August 12, 2015 Published: September 23, 2015

doi:10.5296/jet.v3i1.8074 URL: http://dx.doi.org/10.5296/jet.v3i1.8074

\begin{abstract}
114 school teachers from two urban schools participated in an online survey focusing on classroom management skills. Results were analyzed using a mixed method approach. Teachers reported confidence in general classroom management skills. Hierarchical regression results indicated significant gender difference in favor of female teachers and positive correlations between perceived value of professional development (PD) and teacher confidence in general classroom management, addressing specific challenging behaviors, and motivating learners. Furthermore, the teachers favored face-to-face methods as compared to web-based options. Implications for developing an understanding of teacher manageability to provide PD experiences to improve day-to-day classroom management practice are discussed.
\end{abstract}

Keywords: classroom management, professional development, urban teachers

\section{Introduction}

Classroom management consists of a wide variety of skills, strategies, and competencies that teachers must use to keep students academically engaged and productive (Han \& Weiss, 2005). The goal of classroom management is not only to prevent or reduce misbehavior, but to also promote student engagement and motivation, and teach students prosocial and desirable behaviors, conflict resolution strategies, self-regulation and problem solving approaches (Kerr \& Nelson, 2010). Effective classroom management “...not only seeks to establish and sustain an orderly environment so students can engage in meaningful academic learning, it also aims to enhance student social and moral growth" (Evertson \& Weinstein, 2006, p. 4). Reaching these goals involves appropriate physical arrangements, clear delineation of rules and expectations (Sprick \& Daniels, 2010), appropriate prompts and cues, predictable schedules 


\section{MInstitute ${ }^{\text {Macrothink }}$}

Journal of Education and Training

ISSN 2330-9709

2016, Vol. 3, No. 1

and routines, and a variety of classroom activities to keep classrooms running smoothly (Sutherland \& Oswald, 2005).

Creating effective learning environments includes but is not limited to developing an orderly and clutter free physical setting. Students should feel welcomed and comfortable discovering new ideas while sharing their learning with others in these classroom environments. In other words, classrooms have to be safe places where all students can problem solve, generate and share new ideas, ask questions when they need help, and feel motivated to learn (Wehby \& Lane, 2009). As pointed out by Good (2014), effective classroom management involves clear alerting of the expectations and checking for the expected behavior (accountability). For example, "complete this assignment in 10 minutes" would require that (a) the teacher has clearly articulated the directions for the assignment and (b) the teacher will evaluate the completed performance. One without the other is incomplete. Frequent evaluation of student performance without the needed reminders or task clarifications may cause frustration in the student. Similarly, too many alerts or prompts without the monitoring of student accountability for completion of the task also may be ineffective. Teachers who are too quick to reinstate order in the classroom without ensuring student readiness can find it difficult to create opportunities to motivate student learning (Putnam, Luiselli, Handler, \& Jefferson, 2003).

Teachers consistently rank classroom management as one of the most challenging aspects of their profession (Good, 2014). For example, an online Teacher Needs Survey examined the responses of 2,334 teachers from 49 States and the District of Columbia. The responding teachers identified several areas of need in terms of furthering their educational practices with regards to classroom management, instructional strategies, classroom diversity, and parental communication (APA 2005-2006). Among all these areas, the highest areas of need were related to classroom management and instructional skills (Coalition for Psychology in Schools and Education, 2006). When teachers have limited preparation or are not confident to address classroom management in positive ways they find the teaching experience to be overly stressful and complex (Ingersoll, 2001). As a consequence, teachers who are less prepared in handling disruptive behavior often rely on reactive and punitive discipline strategies when compared to more experienced teachers (Yoon, 2002). Not only that, these teachers may tend to focus their attention on the aversive and negative behaviors of their students, rather than on the positive behaviors of their students (Wolff, van den Bogert, Jarodzka, \& Boshuizen, 2015).

\subsection{Need for Professional Development in Classroom Management}

One way to support novice teachers, and in some cases more experienced teachers, with developing effective classroom climates is to provide professional development (PD) on stateof-the-art techniques that promote classroom engagement, learning, and prosocial behaviors. PD can be described as one of the means by which teachers continue to develop their professional skills and knowledge (Bechtel \& O'Sullivan, 2006). PD goes beyond traditional in-service training (Bellanca, 2008). In in-service training, information is presented on a specific topic of interest or need, but no effort is made to ensure how teachers can participate in reforming their own practice (Billingsley, 2005). On the other hand, PD refers to an ongoing, planned, and systemic process geared to produce accountable, goal-directed changes. When teachers are able 
to engage in personal evaluation of their own capabilities to organize and execute PD to attain designated goals, they are likely to find these experiences relevant and meaningful to transform their classroom practices (Safran \& Safran, 1988).

Teachers' views and needs should be considered important in designing the PD opportunities (Guskey, 2002; Safran, Safran, \& Barcikowski, 1990). When teacher views and beliefs about their own practice are considered in designing professional enhancement opportunities, they are more likely to adopt new approaches and refine their existing practices (Duchaine, Jolivette, \& Fredrick, 2011). Providing feedback to them about their views and perceptions is also essential for improving their practice. Coaching, mentoring, or study group experiences can be structured to provide support for their professional learning (Darling-Hammond, Chung-Wei, Andree, Richardson, \& Orphanos, 2009). Teachers who develop their professional skills through PD feel more competent and efficacious in handling challenges in their jobs (Egyed \& Short, 2006). They are more likely to accept the challenges of classroom management and feel more confident when they believe that they have acquired the skills to handle them (Guskey, 2002). Teachers who are confident and believe that they will be successful are likely to set higher goals for themselves and their students. They are more likely to try harder to achieve those goals, and persist through obstacles than teachers who are not as confident and selfassured (Wehby \& Lane, 2009). Through PD opportunities, teachers with varying levels of confidence can share new learning, practice new skills with peers, seek input and feedback on their new ideas prior to returning to the classroom.

Relative to their predecessors, teachers presently enjoy a greater variety of PD offerings. Modalities such as online courses, webinars, and virtual conferences have begun to replace inperson conferences where they often had the chance to hear multiple speakers on topics related to behavior management (Mathur, Estes, \& Johns, 2012). Despite such abundance of choices and opportunities, urban educators may still find it difficult to make decisions about which PD opportunities to select because of the unique challenges associated with their own settings and student populations. First, they may find themselves uncertain about the relevance of the topics. Second, they may also struggle with issues such as limited time, over work, and district level concerns such as availability of substitute teachers and funding. Third, they may view spending hours on receiving information that that they cannot implement in their own context as meaningless. To add to the complexity, research also suggests that hours spent in PD do not necessarily differentiate between more and less effective teachers (Harris \& Sass, 2007). Therefore, it is important to examine how urban educators view their PD choices and how they view their PD experiences in relationship to their own classroom management.

\subsection{Urban Teachers and Their PD Needs}

Many urban schools face significant challenges with delivering high-quality instruction. These challenges include poverty, violence, social disadvantage, transient populations, and family instability (Boyd \& Shouse, 1997; Kincheloe, 2010) which are external factors that influence the schools experience. Factors within the school such as overcrowding, large class sizes, deteriorating physical conditions, and large numbers of students with unmet learning and mental health needs (Cappella, Frazier, Atkins, Schoenwald, \& Glisson, 2008; Kataoka, Zhang, 


\section{Mll Macrothink}

Journal of Education and Training

ISSN 2330-9709

2016, Vol. 3, No. 1

\& Wells, 2002) also influence student learning in these schools. These internal conditions serve as stressors for many of the teachers working in high-poverty, urban schools (Shernoff, Mehta, Atkins, Torf, \& Spencer, 2011). To be successful, teachers of urban populations must have complex understandings of urban issues and the confidence to positively address diverse academic and behavioral needs of their students. In urban schools, examples of student misbehavior range from a simple off-task behavior to distractibility, disengagement, lack of motivation for learning, and mistrust for authority figures in the classroom (Epstein, et al., 2008; Kulinna, Cothran, \& Regualos, 2003). Teacher preparation programs do not always focus upon specific behavioral issues that are unique to urban contexts. Thus, urban teachers' views and perceptions are important to consider and incorporate while developing or selecting PD opportunities.

Despite mounting evidence supporting the ineffectiveness of punitive disciplinary procedures, many teachers in urban settings rely on reactive and punitive management approaches (Shernoff et al., 2011) because they may lack knowledge about other options. When faced with frequent classroom disruptions, many of them view the behaviors as obstacles that need to be removed. Several of them end up using suspension and expulsion and removing the student from the instructional environment to reinstate the order in their classrooms (Reinke, Herman, $\&$ Stormont, 2011). These punitive approaches have been identified as predictive of school dropout (Balfanz, Spiridakis, Neild, \& Legters, 2003; Sinclair, Christenson, \& Thurlow, 2005) and increase the likelihood of student involvement with the juvenile justice system (Fabelo, Thompson, Plotkin, Carmichael, Marchbanks, \& Booth, 2011).

Teachers in classrooms with higher rates of disruptive behavior view themselves as less efficacious and end up using harsh reprimands (Reinke et al., 2011). Continuously addressing student misbehavior for extended periods of time can be an emotionally and physically draining experience for teachers of all experience levels. It may also lead to emotional exhaustion, high stress levels, apathy, and depersonalization (Tsouloupas, Carson, Matthews, Grawitch, \& Barber, 2010). It can be overwhelming to feel the isolation and stress of handling students' behavioral issues single handedly for several hours each day.

Evidence also suggests that confident teachers view student misbehavior as an opportunity for new learning (Freiberg, Huzinec, \& Templeton, 2009). When they notice a disruption has occurred, they engage in a systematic problem solving process to decide whether they need to confront the situation by reprimanding the misbehaving student, by teaching more adaptive behaviors to the student, and/or by increasing active student responding (Lewis, Hudson, Richter, \& Johnson, 2004). Thus, it is important that teachers in urban settings have access to professional enhancement opportunities that they value and where they can learn and share new strategies that are specific to issues that they have to handle so they feel more competent, empowered, and confident in dealing with students' specific behavioral issues.

\section{Context of the Study}

This study originated in the southwestern United States in response to two principals' requests for more information about effective classroom management in an urban context. The principals reported that more than $35 \%$ of their teachers were spending 30 minutes to 2 hours 


\section{Mll Macrothink}

Journal of Education and Training

ISSN 2330-9709

2016, Vol. 3, No. 1

daily in handling behavioral issues. Their staff turnover rate was $45 \%$ and student absenteeism and suspension rates were $11 \%$ and $7 \%$, respectively. The principals were attending a national conference and were participants in a statewide Positive Behavior Intervention Supports (PBIS) team. They requested one of the researchers to identify PD needs in the area of classroom management for their urban schools. The schools were in the process of training school-level faculty and staff to implement positive behavioral interventions and supports within the classrooms (Safran \& Oswald, 2003). More specifically, these principals were interested in teachers' self-reported perceptions of classroom management skills in relation to student behavioral issues. They thought it was critical to find which aspects of classroom management were more important for them, how they defined classroom management in general, and how confident they viewed themselves in handling student behavioral challenges in their own settings (Scott \& Caron, 2006). The goal of this study was to understand urban teachers' views related to effective classroom management. The purpose of the study was to examine the following research questions:

1) How do teachers in urban settings define classroom management and what strength(s) do they think they have in managing their classrooms?

2) What are the most common challenging behaviors of students reported by the teachers?

3) What are the preferred modalities for PD?

4) Do teachers' demographic characteristics, hours of PD, and perceived value of PD predict teachers' self-reported perceptions of effective classroom skills?

5) Do the above teacher characteristics interact to predict teachers' self-reported perceptions of classroom management skills?

6) How do principals use teacher views of classroom management in developing PD experiences?

\section{Method}

\subsection{Participants}

Teachers were recruited for the study from two urban schools located in a large city in the southwestern United States. Both schools served a primarily low socioeconomic population of students with $80 \%$ or above students receiving free or reduced lunch. A large number of the students served by the two schools were second-language learners with $50 \%$ being primarily Spanish speakers. The average annual income for the neighborhood residents represented by these schools was $\$ 35,000$.

114 of the $162 \mathrm{~K}-8$ teachers from the two schools completed the survey for a $70.3 \%$ response rate. $79.6 \%$ of the sample reported their gender as female. The teachers reported state certification in the following areas: $79.6 \%$ elementary school, $12.4 \%$ secondary grades, $6.2 \%$ special education, and $1.8 \%$ early childhood education. $33.3 \%$ were between 21 and 30 years of age, 28.1\% were between 31 and 40, 19.3\% were between 41 and 50, 18.4\% were between 51 and 60 , and $.9 \%$ were older than 61 . The ethnicity was as follows: $72 \%$ Caucasian, $4 \%$ 


\section{MInstitute ${ }^{m}$ Macrothink}

African American, 20\% Mexican American, 2\% Asian American, and 2\% Native American.

Two principals of the participating schools also engaged in the process of developing the survey and in a follow-up interview. Both principals were Caucasian males, had master's degrees in educational leadership and were 45 and 48 years old.

\subsection{Instrumentation}

Based on the review of literature (Brophy, 2012; Hattie, 2009; Scott, Anderson, \& Alter, 2012) and our prior work (Mathur et al., 2012), we developed a survey that measured perceptions of teacher practices as they relate to classroom management. The basic competencies of classroom management that the two school principals agreed upon included delivering positive reinforcement; using instructional cues; prompting; using a variety of classroom activities; and using behavioral data for decision-making. An expert group of three teachers and three researchers cross checked the list of items and included various classroom management practices that teachers need to use, such as, using antecedent control and dealing with specific problem behaviors. Items were then cross referenced with a 5-point Likert scale indicating the extent to which teachers perceived themselves as being prepared in the listed classroom management practices. Research indicates that special educators experience high incidents of problem behaviors (e.g., Safran \& Safran, 1988), therefore, the survey was piloted with 10 special education teachers from an urban setting. Based on their suggestions, the survey was further revised to focus on (a) the basic classroom management practices consisting of using reinforcement, cues and prompts, (b) specific student behavioral challenges that teachers face such as internalizing, externalizing, and covert behaviors, and (c) the challenge of motivating students to learn. In addition, five items measuring the value of PD for classroom management were added. As a result of the pilot study, wording and survey items were further modified and refined to further align the items with the research questions of this study (Marley, 2010; Marley \& Levin, 2011).

The final online survey consisted of three sections. The first section focused on demographics of the teachers, the second section asked about challenging student behaviors and PD experiences, and the third section asked about teachers' perceptions of their personal skill in classroom management, managing challenging behaviors, motivating students and the value of PD. To reduce response burden of the participants the quantitative variables of age, years of teaching, time spent managing student behavioral challenges, and hours of PD in behavior management were provided intervals with ranges of values.

The perceptions variables, located in the third section of the survey, were measured using Likert scales with response options from one to five, with one signifying "not at all" and five "a lot" (see Appendix A for scale content). Perception of basic classroom management abilities consisted of five items that asked respondents broad questions about classroom management (Cronbach's $\alpha=.76$ ). Managing specific challenging behaviors was measured with three items related to the internalizing, externalizing, and covert behaviors of students $(\alpha=.73)$, motivating students consisted of two items $(\alpha=.81)$. Teachers' perceptions of the value of professional development was measured with five items $(\alpha=.82)$. In addition, the survey contained two open ended items. The first question focused on how participants defined classroom 


\section{1) Macrothink}

Journal of Education and Training

ISSN 2330-9709

2016, Vol. 3, No. 1

management and their perceived strengths in this arena and the second was about commonly experienced problem behaviors in their classrooms.

\subsection{Procedures}

Teachers were contacted via email to participate in the study. The email contained a link to an online survey that asked questions related to demographic characteristics, the most challenging behaviors presented by students, ratings of perceived value of professional development, and ratings of teacher perceptions of classroom skills. Upon completion, the participants were thanked for their participation. All procedures were approved by the authors' institutional review board prior to enacting the study.

A follow-up open-ended interview was conducted with the two principals after the survey was complete. The two principals were asked one question: How do you think your understanding of teachers' views through the survey influenced the design and delivery of PD experiences this year?

\subsection{Analysis}

A mixed method approach was applied to analyze the survey data. Qualitative analysis was conducted for the first two research questions related to the definition of classroom management and commonly reported problem behaviors. These open-ended responses were analyzed using Miles and Huberman's (1994) process for coding and categorizing qualitative data. After identifying the themes that emerged in the initial analysis, specific responses were coded.

Three hierarchical multiple regressions (Cohen, Cohen, West \& Aiken, 2003) were used to assess whether perceptions of PD value and hours of PD predict self-reported perceptions of ability in: classroom management, managing inappropriate behaviors and motivating students. The demographic characteristics of minority status, gender, age, years teaching and time spent on classroom problems were entered as a first block; hours of PD and perception of PD value were added as a second block, and the interactions of hours of PD and years of teaching with perceptions of PD value as a third block. Prior to analyses the assumptions associated with multiple regression were assessed (i.e., normality, linear relationship, etc.) and none were found to be untenable. The variables that varied by degree - age, years teaching, time spent on problems, hours of $\mathrm{PD}$, and value of $\mathrm{PD}$ - were standardized by calculating $\mathrm{z}$ scores. The interactions terms constructed by calculating the product of the factors of interest. The overall results are presented in response to the six research questions.

\section{Results}

4.1 RQ 1. How do teachers in urban settings define classroom management and what strength(s) do they think they have in managing their classrooms?

The open ended question, "How do you define classroom management and what strength(s) do you think you have in managing your classroom?" was analyzed using codes and themes (Miles \& Huberman, 1994). Based on this analysis, classroom management was defined as an "environment that is orderly and organized where teachers can teach and student can learn." 


\section{Mll Macrothink}

Journal of Education and Training

ISSN 2330-9709

2016, Vol. 3, No. 1

The descriptors were identified, coded, and three themes became apparent providing the core of the process: (a) antecedent based programming for establishing positive environment; (b) engaging students through motivation and positive reinforcement; and (c) promoting compliance and on-task behavior. These themes were identified based on teacher responses that included descriptors such as "the classroom is managed when students are staying on task"; "when there are no deviation in expectations"; "it means setting rules and routines"; "it means establishing controlled and compliant environment," "it means having an environment that is good for promoting learning and teaching". Teacher strengths in these settings included: managing antecedents such as rules, schedules, structures, planning time, expectations (36\%); creating engaging environments through motivation (19\%), using positive reinforcement (23\%); staying calm during power struggles (4\%); and staying consistent (5\%). Other responses that were idiosyncratic and did not fall in any category included: offering individualized programming; using class DOJO; using humor; being an alpha female; using a variety of interventions; building relationships; effective communication; flexibility; and offering students opportunity to save face.

In response to the survey focusing on classroom management issues, the respondents reported a highest mean rating for confidence in applying basic classroom management strategies $(M=4.42, S D=.703))$, using positive reinforcement $(M=4.36, S D=.832)$, and using prompts and cues $(M=4.36, S D=.788)$, respectively. Teachers reported low confidence in their preparedness for dealing with specific behavioral challenges related to externalizing behaviors, internalizing behaviors and covert behaviors (see Table 1). In addition, the teachers reported a mean rating in the middle of the scale for using data in making decisions about classroom management; indicating that data-informed decision making regarding behavioral support may need further development (see Table 1).

\subsection{RQ2. What are the most common challenging behaviors of students reported by the teachers?}

In the open-ended question where the respondents were asked to identify three classroom challenges that they faced, the 114 respondents identified 51 behavioral issues. Analysis of the coded responses discovered that the most commonly stated challenging behaviors were disrespect, challenging authority by not following directions and showing noncompliance $(n=$ 26, 23\%), not listening/inattention $(n=26,23 \%)$, lack of readiness/lack of interest/not motivated to learn $(n=21,19 \%)$ and talking out/not waiting for turn $(n=17,15 \%)$.

\subsection{RQ3. What are the preferred modalities for delivery of professional development?}

Participants were asked to rank order the PD modality they would like to receive. This question generated 114 responses indicating preference for face-to-face methods over web-based or online methods. Results indicate that most educators preferred district staff development as their first choice ( $n=48,42.1 \%)$, conferences as a second choice $(n=36,31.57 \%)$ followed by mentoring $(n=19,16.66 \%)$ and study groups $(n=16,14.03 \%)$. The least preferred methods included virtual networking $(n=9,7.89 \%)$ and forums $(n=9,7.89 \%)$, and university courses $(n=7,6.14 \%)$. When asked what PD options were available to teachers during the year the most commonly identified response was in-school staff development followed by 
conferences and then webinars.

$4.4 R Q s 4$ \&5. Do teachers' demographic characteristics, hours of professional development, and perceived value of professional development predict teachers'self-reported perceptions of effective classroom management skills? Do the above teacher characteristics interact to predict teachers'self-reported perceptions of classroom management skills?

The means of the perceptions variables and their correlations are reported in Table 2. The following paragraphs report the statistically significant results with a type I error rate set of .05.

\subsubsection{Perceptions of Classroom Management}

The first block of the regression model (see Table 3) containing demographic characteristics was statistically significant, $F(5,108)=2.950, R^{2}=.120, p=.016$. The second and third blocks consisting of hours and perceptions of professional development and their interactions did not significantly predict an additional variance in classroom management skills (both $p s>.05$ ). Therefore, the results of the first regression model were interpreted. The main effect of gender was statistically significant with females reporting greater perceptions of their abilities in classroom management skills than males, $B=.283$, $s r=.221, p=.016$.

\subsubsection{Perceptions of Working with Challenging Student Behaviors}

The first block of the regression model (see Table 4 ) was not statistically significant, $F(5,108)=$ $1.397, R^{2}=.061, p=.231$. The second model adding the hours and value of professional development accounted for a statistically significant amount of variance in challenging behaviors, $F(7,106)=41.161, p<.001, R^{2}=.743$. The inclusion of the interactions in the third model did not account for a statistically significant amount of variance in the outcome $(p>.05)$. Therefore, the second model was interpreted. Results indicated that perceived value of professional development was a positive predictor of perceived ability to handle specific challenging student behaviors, $B=.706, s r=.816 . p<.001)$.

\subsubsection{Motivating Students}

The first block of the regression model (see Table 5 ) was not statistically significant, $F(5,108)$ $=1.864, R^{2}=.079, p=.107$. The addition of value of professional development in the second model accounted for a statistically significant amount of variance in motivating behaviors, $F(7$, $106)=2.798, R^{2}=.156, p=.010$. The inclusion of the interactions in the third model did not account for a statistically significant amount of variance in the outcome $(p>.05)$. Therefore, the second model was interpreted. The results indicated that perceived value of professional development was a positive predictor of perceived ability to motivate students, $B=.186, \mathrm{sr}$ $=.261, p=.004$. In addition, gender was statistically significant with female teachers reporting greater perceptions of their ability to motivate students, $B=.295, s r=.156, p=.050$, than male teachers. 


\section{1) Macrothink}

Journal of Education and Training

ISSN 2330-9709

2016, Vol. 3, No. 1

4.5 RQ6. How do principals use teacher views of classroom management in developing PD experiences?

After the survey data were analyzed, both the two principals were interviewed and were asked one question: "How do you think your understanding of teachers' views through the survey influenced the design and delivery of PD experiences this year?" The principals' responses indicated themes that they identified for the PD experiences for the year and supports they would be making available after teachers had gone through the PD experiences. The principals indicated satisfaction with teachers' confidence in using basic classroom management skills; however, they were concerned about teachers' lack of preparedness in dealing with specific behavioral challenges, motivating students for learning, and keeping them engaged. One principal said "I am not surprised by their [teachers] lack of self-reported confidence in databased decision making; we've never asked them to engage in this process". Based on this analysis, they identified two themes for PD for the following year: How to keep students motivated and engaged and how to make data based decisions. The principals organized two sessions a semester focusing on these topics and provided supplemental supports such as coaching and mentoring for selected teachers (Darling-Hammond et al., 2009).

Table 1. Means and Standard Deviations of Perceptions of Classroom Management Abilities by Ratings ( 1 = "not at all" and 5 = "a lot.")

\begin{tabular}{|c|c|c|}
\hline To what extent: & Mean & $\begin{array}{l}\text { Standard } \\
\text { Deviation }\end{array}$ \\
\hline Are you confident in using classroom management strategies? & 4.42 & .703 \\
\hline $\begin{array}{l}\text { Do you use positive reinforcement with your students in your } \\
\text { classroom? }\end{array}$ & 4.36 & .832 \\
\hline $\begin{array}{l}\text { Do you use prompts and cues for encouraging students to engage } \\
\text { in appropriate classroom behavior? }\end{array}$ & 4.36 & .788 \\
\hline Do you find yourself prepared in motivating students for learning? & 4.20 & .766 \\
\hline $\begin{array}{l}\text { Do you find yourself prepared in maintaining students' attention } \\
\text { and their focus on task? }\end{array}$ & 4.14 & .693 \\
\hline $\begin{array}{l}\text { Do you use data to identify students who need additional } \\
\text { behavioral supports? }\end{array}$ & 3.34 & 1.197 \\
\hline $\begin{array}{l}\text { Are you prepared in dealing with students who display covert } \\
\text { disorders such as lying, stealing, etc.? }\end{array}$ & 3.31 & .897 \\
\hline $\begin{array}{l}\text { Are you prepared in dealing with students who show externalizing } \\
\text { behavior problems, such as aggressive behavior, kicking, fighting } \\
\text { with others? }\end{array}$ & 3.25 & 1.102 \\
\hline $\begin{array}{l}\text { Are you prepared in dealing with students who show internalizing } \\
\text { behavior problems, such as depression, anxiety, withdrawal, etc.? }\end{array}$ & 3.04 & 1.069 \\
\hline
\end{tabular}




\section{Macrothink

Table 2. Pearson's Correlations of Perceptions Variables (Means and Standard Deviations on Diagonal).

\begin{tabular}{lllll}
\hline & V1 & V2 & V3 & V4 \\
\hline V1: Management & $4.01(0.51)$ & & & \\
V2: Challenging Behaviors & $.21^{*}$ & $3.32(0.66)$ & & \\
V3: Motivating Students & $.39^{* *}$ & $.27^{* *}$ & $3.20(0.82)$ & \\
V4:Professional & .14 & $.85^{* *}$ & $.29^{* *}$ & $4.16(0.67)$ \\
Development Value & & & & \\
\hline
\end{tabular}

Note: $* *$ Correlation is significant at the 0.01 level (2-tailed).

* Correlation is significant at the 0.05 level (2-tailed).

Table 3. Hierarchical Regression of Perceptions of Classroom Management Skills

\begin{tabular}{|c|c|c|c|c|c|c|c|c|c|c|c|c|}
\hline \multirow{3}{*}{ Variable } & \multicolumn{12}{|c|}{ Self-reported Perceptions of Classroom Management Skills } \\
\hline & \multicolumn{4}{|c|}{ Model 1} & \multicolumn{4}{|c|}{ Model 2} & \multicolumn{4}{|c|}{ Model 3} \\
\hline & $B$ & $S E$ & $p$ & $s r$ & $B$ & $S E$ & $p$ & $s r$ & $B$ & $S E$ & $p$ & $s r$ \\
\hline Constant & 3.754 & .108 & $<.001$ & & 3.760 & .109 & $<.001$ & & 3.781 & .111 & $<.001$ & \\
\hline Gender $($ female $=1)$ & .283 & .115 & .016 & .221 & .278 & .116 & .018 & .217 & .250 & .119 & .039 & .190 \\
\hline Race (minority = 1) & .009 & .071 & .898 & .012 & -.008 & .073 & .908 & -.010 & -.001 & .074 & .989 & -.001 \\
\hline Age & .110 & .101 & .278 & .098 & .104 & .102 & .307 & .093 & .101 & .103 & .330 & .089 \\
\hline Years Teaching & .110 & .071 & .123 & .140 & .126 & .073 & .089 & .156 & .119 & .074 & .110 & .146 \\
\hline Time Spent on Classroom & -.058 & .047 & .216 & -.112 & -.050 & .048 & .302 & -.094 & -.048 & .048 & .315 & -.092 \\
\hline \multicolumn{13}{|l|}{ Problems } \\
\hline Hours of Professional & & & & & .016 & .049 & .752 & .029 & .016 & .049 & .748 & .029 \\
\hline \multicolumn{13}{|l|}{ Development } \\
\hline Value of Professional & & & & & .055 & .049 & .269 & .101 & .046 & .052 & .379 & .080 \\
\hline \multicolumn{13}{|l|}{ Development } \\
\hline Value of Professional & & & & & & & & & .027 & .043 & .521 & .059 \\
\hline \multicolumn{13}{|l|}{ Development by Hours of } \\
\hline \multicolumn{13}{|l|}{ Professional Development } \\
\hline Value of Professional & & & & & & & & & .046 & .051 & .360 & .084 \\
\hline \multicolumn{13}{|l|}{ Development by Years of } \\
\hline \multicolumn{13}{|l|}{ Teaching } \\
\hline$R^{2}$ & .120 & & & & .131 & & & & .141 & & & \\
\hline$F$ & 2.950 & & .016 & & 2.286 & & .033 & & 1.892 & & .061 & \\
\hline$\Delta R^{2}$ & & & & & .011 & & & & .010 & & & \\
\hline$\Delta F$ & & & & & .669 & & .514 & & .579 & & .563 & \\
\hline
\end{tabular}


Table 4. Hierarchical Regression of Perceptions of Ability in Working with Challenging Student Behaviors

\begin{tabular}{|c|c|c|c|c|c|c|c|c|c|c|c|c|}
\hline \multirow{3}{*}{ Variable } & \multicolumn{12}{|c|}{ Self-reported Perceptions of Working with Challenging Student Behaviors } \\
\hline & \multicolumn{4}{|c|}{ Model 1} & \multicolumn{4}{|c|}{ Model 2} & \multicolumn{4}{|c|}{ Model 3} \\
\hline & $B$ & $S E$ & $p$ & $s r$ & $B$ & $S E$ & $p$ & $s r$ & $B$ & $S E$ & $p$ & $s r$ \\
\hline Constant & 3.264 & .177 & $<.001$ & & 3.328 & .096 & $<.001$ & & 3.342 & .098 & $<.001$ & \\
\hline Gender $($ female $=1)$ & -.107 & .189 & .572 & .047 & -.144 & .102 & .161 & -.071 & -.168 & .105 & .114 & -.081 \\
\hline Race $($ minority $=1)$ & .157 & .117 & .180 & -.053 & -.065 & .064 & .314 & -.051 & -.063 & .065 & .339 & -.049 \\
\hline Age & .084 & .165 & .612 & .126 & -.030 & .090 & .739 & -.017 & -.024 & .091 & .788 & -.014 \\
\hline Years Teaching & -.060 & .116 & .605 & -.048 & .064 & .065 & .322 & .050 & .061 & .065 & .347 & .048 \\
\hline $\begin{array}{l}\text { Time Spent on Classroom } \\
\text { Problems }\end{array}$ & -.132 & .077 & .087 & -.161 & -.011 & .042 & .788 & -.014 & -.010 & .042 & .805 & -.012 \\
\hline $\begin{array}{l}\text { Hours of Professional } \\
\text { Development }\end{array}$ & & & & & .043 & .195 & -.066 & -.057 & .043 & .189 & -.067 & -.056 \\
\hline $\begin{array}{l}\text { Value of Professional } \\
\text { Development }\end{array}$ & & & & & .706 & .044 & $<.001$ & .816 & .692 & .045 & $<.001$ & .769 \\
\hline $\begin{array}{l}\text { Value of Professional } \\
\text { Development by Hours of } \\
\text { Professional Development }\end{array}$ & & & & & & & & & -.003 & .037 & .942 & -.004 \\
\hline $\begin{array}{l}\text { Value of Professional } \\
\text { Development by Years of } \\
\text { Teaching }\end{array}$ & & & & & & & & & .049 & .044 & .275 & .056 \\
\hline$R^{2}$ & .061 & & & & .731 & & & & .734 & & & \\
\hline$F$ & 1.397 & & .231 & & 41.161 & & $<.001$ & & 31.92 & & & \\
\hline$\Delta R^{2}$ & & & & & .670 & & & & .003 & & & \\
\hline$\Delta F$ & & & & & 132.08 & & $<.001$ & & .540 & & & \\
\hline
\end{tabular}

Table 5. Hierarchical Regression of Perceptions of Preparedness to Motivate Students

\begin{tabular}{|c|c|c|c|c|c|c|c|c|c|c|c|c|}
\hline \multirow{3}{*}{ Variable } & \multicolumn{12}{|c|}{ Self-reported Perceptions of Preparedness to Motivate Students } \\
\hline & \multicolumn{4}{|c|}{ Model 1} & \multicolumn{4}{|c|}{ Model 2} & \multicolumn{4}{|c|}{ Model 3} \\
\hline & $B$ & $S E$ & $p$ & $s r$ & $B$ & $S E$ & $p$ & $s r$ & $B$ & $S E$ & $p$ & $s r$ \\
\hline Constant & 3.955 & .144 & $<.001$ & & 3.969 & .140 & $<.001$ & & 3.997 & .142 & $<.001$ & \\
\hline Gender $($ female $=1)$ & .298 & .154 & .055 & .179 & .295 & .149 & .050 & .177 & .268 & .153 & .082 & .156 \\
\hline Race (minority $=1$ ) & -.023 & .095 & .812 & -.022 & -.080 & .094 & .394 & -.076 & -.066 & .094 & .488 & -.062 \\
\hline Age & -.081 & .134 & .548 & -.056 & -.119 & .131 & .363 & -.081 & -.141 & .132 & .286 & -.096 \\
\hline Years Teaching & .101 & .095 & .285 & .099 & .119 & .094 & .210 & .113 & .106 & .094 & .266 & .100 \\
\hline $\begin{array}{l}\text { Time Spent on } \\
\text { Classroom Problems }\end{array}$ & -.114 & .063 & .070 & -.169 & -.081 & .061 & .190 & -.118 & -.080 & .061 & .196 & -.116 \\
\hline $\begin{array}{l}\text { Hours of Professional } \\
\text { Development }\end{array}$ & & & & & -.065 & .063 & .302 & -.093 & -.062 & .063 & .325 & -.088 \\
\hline $\begin{array}{l}\text { Value of Professional } \\
\text { Development }\end{array}$ & & & & & .186 & .063 & .004 & .261 & .189 & .066 & .005 & .255 \\
\hline $\begin{array}{l}\text { Value of Professional } \\
\text { Development by } \\
\text { Hours of Professional } \\
\text { Development }\end{array}$ & & & & & & & & & .081 & .054 & .138 & .133 \\
\hline $\begin{array}{l}\text { Value of Professional } \\
\text { Development by Years } \\
\text { of Teaching }\end{array}$ & & & & & & & & & .025 & .065 & .699 & .035 \\
\hline$R^{2}$ & .079 & & & & .156 & & & & .174 & & & \\
\hline$F$ & 1.864 & & .107 & & 2.798 & & .010 & & 2.438 & & .015 & \\
\hline$\Delta R^{2}$ & & & & & .077 & & & & .018 & & & \\
\hline$\Delta F$ & & & & & 4.805 & & .010 & & 1.148 & & .321 & \\
\hline
\end{tabular}




\section{Mll Macrothink}

\section{Discussion}

The study examined six questions focusing on (a) the definition of classroom management and teacher reported strengths in classroom management; (b) most common challenging behaviors of students reported by the teachers; (c) teachers' preferred modalities of delivery for PD; (d) demographic characteristics, hours of professional development, and perceived value of PD that predict teachers' self-reported perceptions of effective classroom management skills; (e) interaction between years of teaching and/or hours of PD with value of PD to predict teachers' self-reported perceptions of classroom management skills; and (e) principals' use of teacher views about classroom management in designing PD experiences.

Classroom management was defined as creating an environment that is orderly and organized where teachers can teach and student can learn. The definition that emerged from the analysis of participants' responses is in congruence with previous research that supports both orderliness and opportunity for learning and teaching as important aspects of classroom management (Evertson \& Weinstein, 2006; Putnam et al., 2003). Urban teachers identified non-compliance, disrespect, talking out and motivating the students for learning as several of their challenges; interestingly, gender was found to be related to the skill of motivating students for learning indicating female urban teachers perceived themselves as more prepared than males in motivating students. Experience of teachers also was positively related to basic classroom management skills and more specifically with the skill of motivating students. These findings are supportive of previous research that indicates expert teachers who have been in the profession for a while focus on learning in the classroom and believe that the teachers have the ability to influence learning; they find themselves able to motivate students, whereas those new to the profession are more concerned with maintaining discipline and behavioral norms (Wolff et al., 2015; Yoon, 2002). In addition, the teachers also self-reported feeling less prepared for data based decision making as compared to other classroom management skills. Administrators of the participating schools utilized these findings in designing PD experiences for their teachers. These findings have implications for creating PD opportunities and experiences to promote these skills in urban teachers (Safran \& Safran, 1988). By using data based decision making teachers can ensure that they are able to create opportunities to motivate students (Putnam, et al. 2003) so they can engage in meaningful academic and social learning (Evertson $\&$ Weinstein, 2006), which is one of the main goals of classroom management.

In this study, the teachers perceived themselves as confident in basic classroom management strategies, such as using positive reinforcement, and prompts and cues for maintaining on-task behaviors of students. This can be attributed to general behavior management coursework that many teachers complete during their teacher preparation. Most behavior management coursework focuses on basic classroom management principles of how to define and reinforce classroom behaviors that are easily detectable (Kerr \& Nelson, 2010). It is possible that teachers found themselves comfortable with using basic behavior management skills of establishing rules, expectations, routines and planning time for setting their classrooms and needed more assistance with individualized student behavioral and motivational needs such as student disengagement, lack of effort, or readiness for learning (Baker, Grant, \& Morlock, 2008). 


\section{Mll Macrothink}

Journal of Education and Training

ISSN 2330-9709

2016, Vol. 3, No. 1

Although research on online professional development has demonstrated a number of benefits for teachers, including convenience of time and access (Varsidas \& Zembylas, 2004), urban teachers in this study preferred face to face methods. Principals in this study used this information and provided teachers with preferred face to face opportunities for PD consisting of collaborative consultation, study groups, and coaching (Driscoll, 2008). Upon further clarification with the principals, it was found that teachers indicated difficulty facing technical challenges such as finding a platform and supporting virtual communities, and oftentimes experienced a steep learning curve (Charalambros, Michalinos, \& Chamberlain, 2004). The findings also indicated that teachers in these schools need additional opportunities to assist students with internalizing behaviors and motivational issues who experience difficulty engaging with teachers and peers; and actively reengage them in learning.

In this study perceived value of PD was positively associated with positive perceptions of teacher preparedness in dealing with specific behavioral challenges and motivating students. Teachers who perceived high value for PD self-reported more confidence and preparedness for dealing with specific behavioral challenges, such as externalizing, internalizing, or covert behaviors and in motivating students. Perhaps teacher preparation programs need to focus on examples of specific behavioral challenges related to externalizing behaviors such as disrespect, noncompliance and aggressive behaviors and internalizing behaviors that reflect disengagement, withdrawal from learning, and motivational issues (Baker et al., 2008).

The study also highlights the importance of systematically collecting data within the urban context and making PD decisions that are beneficial for urban teachers. In a follow-up session, researchers and principals shared these findings with the participating teachers and raised their awareness about the need for PD in the areas of dealing with specific behavioral challenges related to externalizing, internalizing, and covert behavior; motivating and engaging students: and data based decision making. Teachers in their conversations and anecdotal reports indicated that having awareness about PD data helped them understand their own needs for dealing with challenging behaviors. The principals were pleased to see that teachers from their schools in general showed more reliance on positive behavioral supports and strategies and understood the importance of reducing their reliance on negative practices. In more recent discussions with one of the principals of the two participating schools, the researchers found that teachers of these schools have been encouraged to use video samples to monitor their own use of positive supports and interventions with their students.

The results suggest that teachers' value for PD was a positive predictor for both managing specific challenging behaviors and being able to motivate students. This may be due to PD experiences being targeted at these key dimensions (externalizing, internalizing, etc.) of classroom management. However, more research is needed to further understand urban teachers' needs in this area. Based on these findings both participating schools opted for implementation of positive behavior supports as a way to start addressing some targeted needs (data-based decision making, dealing with specific behavioral challenges) highlighted in this study. Just as teachers need PD to enhance their skills in classroom management, students displaying challenging behavior need the assistance of their teachers. Many of these students are at risk for academic failure and dropout (Sinclair et al., 2005), development of additional 


\section{Mll Macrothink}

Journal of Education and Training

ISSN 2330-9709

2016, Vol. 3, No. 1

mental health disorders, and involvement in the juvenile justice system (Farmer, Burns, Phillips, Angold, \& Costello, 2003). They need optimal academic assistance and positive behavioral supports by confident teachers (Egyed \& Short, 2006) who are skilled in proactive management and active teaching (Good, 2014; Lewis et al., 2004). Although teachers from participating schools viewed themselves as having strengths in managing antecedents such as rules, schedules, and expectations (Conroy, Asmus, Boyd, Ladwig, \& Sellers, 2007), they could benefit from additional PD in providing individualized supports to students who experience specific behavioral and motivational issues (Guskey, 2002; Reinke et al., 2011). Future research that examines various PD and models both within and across urban schools needs to be further explored (Desimone, 2009).

One of the limitations of this study is the use of a community sample. The sample was selected because of the request of the two principals for the researchers to provide support in the development of PD opportunities for their respective schools. Given that the sample may not be representative of all populations of teachers, the results of the study may not generalize to all urban schools and should be interpreted with caution (Marley \& Levin, 2011). However, the results are compelling and should be considered for replication and extension with samples from other urban districts. Future studies should examine multiple school districts in rural, urban, and suburban areas to determine crucial components of PD programming for improving classroom management skills of teachers while still controlling for contextual variables. Also, student learning and performance need to be further studied in relation to classroom management.

\section{Conclusion}

Effective classroom management influences teacher instructional practices in the classroom, and also long-term choices about remaining in the profession. The findings from this study have implications for developing PD opportunities taking into consideration the views of urban teachers. It was critical to find what aspects of classroom management were more important for urban teachers and how confident they viewed themselves in handling specific behavioral challenges in their own settings (Scott \& Caron, 2006). These finding have implications for developing coursework in classroom management that focuses on specific behavioral challenges for teacher preparation. More district administrators need to engage in continuous evaluation of their PD in order to provide the most effective support for all of their teachers in the area of classroom management. When urban teachers view themselves as skilled classroom managers and engage in more positive behavior management practices, they may improve their instructional capacity, and, in doing so, positively impact student performance.

\section{References}

Baker, J. A., Grant, S., \& Morlock, L. (2008). The teacher-student relationship as a developmental context for children with internalizing and externalizing behavior problems. School Psychology Quarterly, 23, 3-15. http://dx.doi.org/10.1037/1045-3830.23.1.3

Balfanz R., Spiridakis, K., Neild, R. C., \& Legters, N. (2003). High poverty secondary schools and the juvenile justice System. In Wald \& Losen (Eds.), Deconstructing the school to prison 
pipeline (pp. 77-78). San Francisco, CA: Jossey-Bass.

Bechtel, P., \& O'Sullivan, M. (2006). Chapter 2: Effective professional development - What we now know. Journal of Teaching in Physical Education, 25, 363-378.

Bellanca, J. (2008). Designing professional development for change: A guide for improving classroom instruction. Thousand Oaks, CA: Corwin Sage.

Billingsley, B. (2005). A leader's framework for supporting new special educators. Journal of Special Education Leadership, 18, 3-7.

Boyd, W., \& Shouse, R. (1997). The problems and promise of urban schools. In H.Walberg, O. Reyes \& R. Weissberg (Eds.), Children and youth: Interdisciplinary perspectives (pp. 141165). Thousand Oaks, CA: Sage.

Brophy, J. (1988). Educating teachers about managing classrooms and students. Teaching and Teacher Education, 4, 1-18. http://dx.doi.org/10.1016/0742-051X(88)90020-0

Brophy, J. (2012). Observational research on generic aspects of classroom teaching. In P. A. Alexander and P. H. Winne (Eds.), Handbook of educational psychology, (2 ${ }^{\text {nd }}$ edition, pp. 755780). New York, NY: Routledge.

Cappella, E., Frazier, S. L., Atkins,M. S., Schoenwald, S. K., \& Glisson, C. (2008). Enhancing schools' capacity to support children in poverty: An ecological model of school-based mental health services. Administration and Policy in Mental Health, 35, 395-409.

Coalition for Psychology in Schools and Education. (2006, August). Report on the Teacher Needs Survey Washington, D.C: American Psychological Association, Center for Psychology in Schools and Education.

Charalambos, V., Michalinos, Z., \& Chamberlain, R. (2004). The design of online learning communities: Critical issues. Educational Media International, 41, 135-143. http://dx.doi.org/10.1080/09523980410001678593

Cohen, C., Cohen, P.,West, S. G. \&Aiken, L. S. (2003). Applied multiple regression/correlation analysis for the behavioral sciences. Lawrence Erlbaum Associates, Mahwah.

Conroy, M.A., Asmus, J.M., Boyd, B.A., Ladwig, C.N., \& Sellers, J.A. (2007). Antecedent classroom factors and disruptive behaviors of children with autism spectrum disorders. Journal of Early Intervention, 30, 19-35.

Darling-Hammond, L., Chung-Wei, R., Andree, A., Richardson, N., \& Orphanos, S. (2009). Professional learning in the learning profession: A status report on teacher development in the U.S. and abroad. National Staff Development Council. Retrieved June 10, 2015 from http://www.nsdc.org/news/NSDCstudy2009.pdf

Desimone, L. (2009). Improving impact studies of teachers' professional development: Toward better conceptualizations and measures. Educational Researcher, 38(3), 181-199. 


\section{Mll Macrothink}

Journal of Education and Training

ISSN 2330-9709

2016, Vol. 3, No. 1

Driscoll, M. J., (2008). Embracing coaching as professional development. Principal Leadership, 9(2), 40-44.

Duchaine, E. L., Jolivette, K., \&Fredrick, L. D. (2011). The effect of teacher coaching with performance feedback on behavior-specific praise in inclusion classrooms. Education and Treatment of Children, 34, 209-227

Egyed, C. J., \& Short, R. J. (2006). Teacher self-efficacy, burnout, experience, and decision to refer a disruptive student. School Psychology International, 27, 462-474. http://dx.doi.org/10.1353/etc.2011.0009

Epstein, M., Atkins, M., Cullinan, D., Kutash, K., Weaver, R., Woodbridge, M., Yu, J., \& Wagner, M. (2008). Reducing behavior problems in the elementary school classroom: A practice guide. Washington, DC: Institute of Education Sciences, U.S. Department of Education.

Evertson, C. M., \& Weistein, C. S. (2006). Classroom management as a field of inquiry. In C. M. Evertson, \& C. S. Weinstein's (Eds.), Handbook of classroom management: Research, practice, and contemporary issues (pp. 3-15). Mahwah, NJ: Lawrence Erlbaum Associates.

Fabelo, T., Thompson, M. D., Plotkin, M., Carmichael, D., Marchbanks, M. P. III, \& Booth E. A. (2011). Breaking schools' rules: A statewide study of how school discipline relates to students' success and juvenile justice involvement. New York, NY; College Station, TX: Council of State Governments Justice Center; Public Policy Research Institute of Texas A\&M University. Retrieved from http://justicecenter.csg.org/files/Breaking_Schools_Rules_Report _Final.pdf

Farmer, E., Burns, B., Phillips, S., Angold, A., \& Costello, E. (2003). Pathways into and through mental health services for children and adolescents. Psychiatric Services, 54,60-66. http://dx.doi.org/10.1176/appi.ps.54.1.60

Freiberg, Huzinec, C. A., \& Templeton, S. M. (2009). Classroom management-A pathway to student achievement: A study of fourteen inner -city elementary schools. Elementary School Journal, 110 (1), 63-80.

Good, T. L. (2010). Forty years of research on teaching 1968-2008: What do we know now that we didn't know then? In R. Marzano (Ed.), On excellence in teaching (pp. 31-62). Bloomington, IN: Solution Tree Press.

Good, T. L. (2014). What do we know about how teachers influence student performance on standardized tests: And why do we know so little about other student outcomes? Teachers College Record, 116, 1-41.

Guskey, T. R. (2002). Professional development and teacher change. Teachers and Teaching, 8, 381-391.

Han, S. S., \& Weiss, B. (2005). Sustainability of teacher implementation of school-based mental health programs. Journal of Abnormal Child Psychology, 33, 665-679.

Harris, D. N., \& Sass, T. R. (2007). Teacher training, teacher quality, and student achievement. 
Washington, DC: National Center for Analysis of Longitudinal Data in Education Research.

Hattie, J. (2009). Visible learning: A synthesis of over 800 meta-analyses relating to achievement. New York: NY Routledge.

Ingersoll, R. (2001). Teacher turnover, teacher shortages, and the organization of schools. Center for the Study of Teaching and Policy, Retrieved September 9, 2010, from http://depts.washington.edu/ctpmail/PDFs/Turnover-Ing-01-2001.pdf

Kataoka, S. H., Zhang L., \& Wells, K. B. (2002). Unmet need for mental health care among U.S. children: Variation by ethnicity and insurance status. American Journal of Psychiatry, 159, 1548-1555. doi: 10.1176/ appi.ajp.159.9.1548

Kerr, M. M., \& Nelson, C. M. (2010). Strategies for addressing behavior problems in the classroom (6th ed.). Upper Saddle River, NJ: Pearson.

Kincheloe, J. L. (2010). Why a book on urban education? In S. Steinberg (Ed), 19 urban questions: Teaching in the city (2nd ed., pp. 1-28). New York, NY: Peter Lang Publishing.

Kulinna, P. H., Cothran, D., \& Regualos, R. (2003). Development of an instrument to measure student disruptive behaviors. Measurement in Physical Education and Exercise Science, 7, 25 41. http://dx.doi.org/10.1207/S15327841mpee 0701_3

Lewis, T., Hudson, S., Richter, M., \& Johnson, N. (2004). Scientifically supported practices in EBS: A proposed approach and brief review of current practices. Behavior Disorders, 29, 247259.

Marley, S. C. (2010). Psychological measurement for specialists in group work. The Journal for Specialists in Group Work, 35(4), 331-348.

Marley, S. C., \& Levin, J. R. (2011). When are prescriptive statements in educational research justified? Educational Psychology Review, 23(2), 197-206.

Miles, M., \& Huberman, A. (1994). Qualitative analysis. Thousand Oakes, CA: SAGE Publications.

Putnam, R.F., Luiselli, J.K., Handler, M.W., \& Jefferson G.L. (2003). Evaluating student discipline practices in a public school through behavioral assessment of office referrals. Behavior Modification, 27, 505-523.

Reinke, W. M., Herman, K. C., \& Stormont, M. (2011). Classroom-level positive behavior supports in schools implementing SW-PBIS: Identifying areas for enhancement. Journal of Positive Behavior Interventions, 15, 39-50. http://dx.doi.org/10.1177/1098300712459079

Safran, S. P., \& Oswald, K. (2003). Positive behavior supports: Can schools reshape disciplinary practices? Exceptional Children, 69, 361-373

Safran, S., \& Safran, J. (1988). Perceptions of problem behaviors: A review and analysis of research. In R.B. Rutherford, C.M. Nelson, \& S.R. Forness (Eds.), Bases of severe behavioral disorders in children and youth (pp. 39-50). Boston: College-Hill. 


\section{1) Macrothink

Safran, S.P., Safran, J.S., \& Barcikowski, R.S. (1990). Predictors of teachers' perceived selfcompetence in classroom management. Psychology in the Schools, 27, 148-155.

Scott, T. M., Anderson, C. M., \& Alter, P. J. (2011). Managing classroom behavior using positive behavior supports. Upper Saddle River, NJ: Pearson.

Scott, T. M., \& Caron, D. (2006). Functional behavior assessment at the school-wide level: Determining predictability and function of typical problem behaviors. Preventing School Failure, 50, 13-20.

Shernoff, E.S., Mehta T.G., Atkins M.S., Torf R., \& Spencer J. (2011). A qualitative study of the sources and impact of stress among urban teachers. School Mental Health, 3, 59-69.

Sinclair, M. F., Christenson, S. L., \& Thurlow, M .L. (2005). Promoting school completion of urban secondary youth with emotional or behavioral disabilities. Exceptional Children, 71, 465-482.

Sprick, R., \& Daniels, K. (2010). Managing student behavior. Principal Leadership, 11, 1821.

Sutherland, K. S., \& Oswald, D. P. (2005). The relationship between teacher and student behavior in classrooms for students with emotional and behavioral disorders: Transactional processes. Journal of Child and Family Studies, 14, 1-14. http://dx.doi.org/10.1007/s10826 005-1106-Z

Tsouloupas, C. N., Carson, R. L., Matthews, R., Grawitch, M. J., \& Barber, L. K. (2010). Exploring the association between teachers' perceived student misbehavior and emotional exhaustion: The importance of teacher efficacy beliefs and emotional regulation. Educational Psychology, 30, 173-189.

Varsidas, C., \& Zambylas, M. (2004. Online professional development: lessons from the field. Education + Training, 46, 326-334.

Wehby, J. H., \& Lane, K. L. (2009). Proactive instructional strategies for classroom management. In A. Akin-Little, S. G. Little, M. A. Bray, \& T. J. Kehle (Eds). Behavioral interventions in schools: Evidence-based positive strategies (pp. 141-156). Washington DC: American Psychological Association.

Wolff, C. E., van den Bogert, N., Jarodzka, H., \& Boshuizen, H. P. A (2015). Keeping an eye on learning: Differences between expert and novice teachers 'representations of classroom management events. Journal of Teacher Education, 66(1) 68-85. http://dx.doi.org/doi.org/ $10.1177 / 0022487114549810$

Yoon, J. S. (2002). Teacher characteristics as predictors of teacher-student relationships: Stress, negative affect, and self-efficacy. Social Behavior and Personality, 30, 485-493. 


\section{Macrothink Mnstitute"}

Appendix 1. Perceptions of Classroom Management Skills and Professional Development Value

Perception of Classroom Management $(\alpha=.76)$

1) To what extent are you confident in using classroom management strategies?

2) To what extent do you use positive reinforcement with your students in your classroom?

3) To what extent do you use prompts and cues for encouraging students to engage in appropriate classroom behavior?

4) To what extent do you think you have the ability to apply various classroom management strategies?

5) To what extent do you use data to identify students who need additional behavioral supports?

Challenging Student Behaviors $(\alpha=.73)$

1) To what extent are you prepared in dealing with students who show internalizing behavior problems, such as depression, anxiety, withdrawal, etc.?

2) To what extent are you prepared in dealing with students who show externalizing behavior problems, such as aggressive behavior, kicking, fighting with others?

3) To what extent are you prepared in dealing with students who display covert disorders such as lying, stealing, etc.?

Motivating Students $(\alpha=.81)$

1) To what extent do you find yourself prepared in maintaining students' attention and their focus on task?

2) To what extent do you find yourself prepared in motivating students for learning?

Perception of Professional Development Value $(\alpha=.82)$

1) To what extent do you agree that professional development increases your capacity for dealing with behavioral issues?

2) To what extent do you agree that professional development makes you more aware of evidenced-based practices in classroom management?

3) To what extent do you agree that professional development opportunities help you in collaborating with other professionals?

4) To what extent does your school provide you with professional development opportunities to manage your classroom effectively?

5) What extent are you able to apply new learning from professional development to your own classroom/setting? 


\section{Copyright Disclaimer}

Copyright reserved by the author(s).

This article is an open-access article distributed under the terms and conditions of the Creative Commons Attribution license (http://creativecommons.org/licenses/by/3.0/). 